
Theoretical \& Applied Science

Bobir Botirovich Parpiev

Candidate of Economic Sciences, a doctoral student department of "Marketing", Faculty "Bank of work" of the Tashkent State Economic University, Senior Researcher,110 al-Khoresmi St . Urgench Uzbekistan

p-ISSN: 2308-4944 (print) e-ISSN: 2409-0085 (online)

Year: 2017 Issue: $01 \quad$ Volume: 45

Published: $30.01 .2017 \quad$ http://T-Science.org

SECTION 31. Economic research, finance, innovation, risk management.

\title{
INCREASING THE MARKETING ACTIVITY EFFICIENCY OF BANKS IN UZBEKISTAN
}

\author{
Abstract: This article reveals the question of creating a modern banking system in Uzbekistan for the \\ formation of the competitive environment in the credit and deposit markets. \\ This article describes the information of a marketing strategy to attract new customers into the commercial \\ banks, in particular, direct and indirect methods of attracting customers tasks of client business, as well as \\ recommendations on the training of highly qualified managers. \\ Key words: credit market, deposit market, the banking system, competition, monobankovskaya system, \\ commercial banks, and marketing. \\ Language: English \\ Citation: Parpiev BB (2017) INCREASING THE MARKETING ACTIVITY EFFICIENCY OF BANKS IN \\ UZBEKISTAN. ISJ Theoretical \& Applied Science, 01 (45): 109-112. \\ Soi: http://s-o-i.org/1.1/TAS-01-45-20 Doi: crossef https://dx.doi.org/10.15863/TAS.2017.01.45.20
}

\section{Introduction}

Updating the economics and implementing deep structural changes in national banking system demands progressive development today. Having gained independency our Republic has carried out consecutive reforms in national bank system liberalization.

However, it is necessary to point out, banks are not competent to use their opportunities to gain their customers' confidence. Therefore, taking into consideration the above mentioned, it is asked to introduce new types of bank services: a) to increase the attraction of people's and economic entities' spare cash capitals to the long-term deposits of commercial banks; b) to increase the long-term credit shares of the country on the strong basis on the account of inner sources.

Effective usage of marketing factors based on scientific research is of great importance especially in both: a) attracting the people's and economic entities' spare cash capitals to the long-term deposits of commercial banks; and b) in improving the bank activity.

Nowadays it is getting very actual to increase the people's and economic entities'- customers' confidence in attracting spare cash and credit capitals, using them wisely and to restrict out-of-bank money circulation.

Successive activity of bank system in market economy and their development depends on the attracting spare cash and credit capitals, and their rational usage. Because, attracting spare cash and credit capitals and using them in important branches of national economy of the country as a credit is considered to be a continuous responsible financial provider of national industry.

\section{Materials and Methods}

The President of the Republic of Uzbekistan pays much attention to the intensification of the bank resources, to provide an active participation of commercial banks in the processes of investment and structural changes of the national economy, amplification of active and passive bank operations. In May 2016 the President adopted a resolution which runs as follows: "Increasing the financial consistency of commercial banks and taking steps and measures for improving their resource base". It is directed to increase the financial invariability and liquidity of commercial banks according to the international standards; reinforcing their resource base; to take measures for widening the bank service spectrum and its quality. This means that attracting spare cash and credit capitals has become a strategic target to the commercial banks.

As a result of increasing the resource base of commercial banks the volume of all the deposits of has been increasing year by year. During the last five years the rate of bank deposit increase has covered over $30 \%$. Attracting spare cash and credit capitals as the main source of the commercial banks gave the result of: a) people's real income has been growing; b) people's 
confidence to the banking system has been growing; c) the countries economy has been growing fast; people's welfare has been growing.

Situation in financial markets and sound competition demands the commercial banks to increase the efficiency of bank services and their types. The banks improving their activity in markets implement new tempting savings activity in order to attract people's spare cash and credit capitals to their deposits. Moreover, it comes in handy to our state leader's resolution "Waging a competition among republican commercial banks on attracting people's spare cash and credit capitals". Accordingly to that annual competition on attracting people's spare cash and credit capitals at the end of each year.

The competition has opened a highway: to speed up attracting people's spare cash and credit capitals activity of commercial banks, improving the quality and types of bank services; introducing the new types of deposits and expanding them taking into consideration the demands and wants of natural persons.

Nowadays the commercial banks suggest their customers over 250 types of savings: - a) in timelimitless and unlimited quantity local and foreign currencies, b) handed in customer's first demand and returned after the agreed term with the customer, c) aimed conditioned savings and others.

It is necessary to point out, that customers can save their money in cash or through money order or currency conversion from their personal deposit accounts in foreign banks.

According to analysis the savings types cover people in all ages. It is reflected in the quantity and deposit amounts of money savers. According to the results of the last International currency deposit research every 1000 deposit-accounts opened by elderly naturalpersons make up 1102 units and it was pointed out that this indicator is the highest among the countries of Commonwealth of newly-Independent States.

Financial stability and development of banking system, principally the deposit volume of people and house holding parties' 2015 semiannual account indicators correspond to a "high degree" appraisal of data. It is in conformity with the President of Uzbekistan Islam Karimov's program measures on deepening and broadening the economic reforms in 2011 - 2015 periods. Particularly, the dynamics of crediting companies deposit volume made up 30'2 \% over the GDP rate of increase; the dynamics of people's savings in banks made up 30'4 \% over the rate of increase of the population real income. The same situation was observed in Kara-Kalpack republic, in all regions of Uzbekistan and in Tashkent. The business-like situation and social-economic development rate indicators should be accounted quarterly.

It is perfectly clear that, bank - customer mutual relations problem reflects the bank's competitiveness. Financial competence of the country's population is less than the desired, but the customers consider that they are served perfectly.

Marketing concept is based on informing all the persons of the economy with all departments' activity. The activity of the bank clients is considered to be more complex than that of the production. Because, servicing the client takes place simultaneously. Thus and so, bank clients are the actual and potential buyers of bank products.

Nowadays, it is important to get answers for the following questions while getting in communication with the customer for the first time - Whether he will become a permanent customer of the bank? Will the first customer-service become useful to the bank? Is it necessary to keep him as a bank customer? [8].

Attracting the new clients to the bank among successful enterprises and organizations shows the degree of the bank client-policy. Practice shows that, to keep the "old" client manages more cheaply than to find and to attract perspective, new clients. If the circle of clients does not extend constantly, If the bank does not improve its skills of maintenance of clients and their attraction the bank will lose its image and, hence, loses its profit.

Generally, the following four functions are very important in client business: a) client attracting; b) keeping the client; c) developing them and the last $-\mathrm{d}$ ) refusing the non-useful client.

Attracting a new client is considered to be an expensive measure. Some instances connected with the problem show that the other forms of client business (e.g. client maintaining) client attracting is twice or three times more expensive [9]. Client attracting technology comprises some important stages such as: a) personnel training; b) seeking the corresponding organizations; c) negotiating with them; d) getting into the way with others e) obtaining positive decisions from potential clients and others.

Client attracting comprises the following: a) information providing preparation; b) organizing preparation; c) manager's psychological readiness on looking for and attracting the new client.

The first two stages are about manager's readiness, as well as about the departments dealing with looking for new clients and attracting them to the bank.

Speaking about the personnel (i.e. about the managers consisting of highly-qualified skillful bankpersonnel group), manager's readiness degree is defined by their skills. For preparing the highly-skilled managers we recommend the following: the specialist should be selected from those who are eager to work at the department and must be prepared. Inviting from other place is non-advisable. Hereby, to our mind, one should pay attention to some morale points of the client attracting manager such as: his honesty, reliability and sincerity.

During attracting new clients to the bank a special definite organizational action program must be worked out. This plan includes the following: a) client 
assessment; b) communication strategy; other actions; client attracting manager's technical opportunities vehicle, communication, advertisement material, identity cards, booklets and others. Corresponding service departments of the bank (house holding department, advertising department and others) should prepare and provide the client attracting manager with them.

There are two ways of finding the potential clients: a) direct (bank-manager's direct communication with the potential client) and b) indirect (through mass-media, by the help of PR-reaction and through other ways of communication) [10].

The ways of direct attraction of new clients are as following:

$\square$ Attracting the new clients through successfully before-serviced clients;

$\square$ Through the mass-media information about successful activities of companies;

$\square$ Through specially-organized conferences, symposiums and exhibitions;

$\square$ Through the offices dealing with the newlyorganized companies and farms' registration;

$\square$ Through the socially-organized by the city and zone meetings information;

$\square \quad$ Through the relatives of the bank personnel;

$\square$ Through the manager's personal relations;

$\square$ Through the attraction of the bankrupted bankclients;

$\square$ Through the additional(non-financial) services of the bank;

$\square$ Through the well-specialized to the market consumers customers;

$\square \quad$ Through the direct-mail system;

$\square \quad$ Through the leading managers.

Looking for this form of clients is as follows:

1. Identifying the potential clients. You can get information about them from managers or from other personnel.

2. Finding and identifying the effective enterprises which need services for improving and expanding their business through mass-media and internet.

3. Making the list and registration of house-holding subjects taking part in symposiums, exhibitions and conferences.

4. Getting information about newly getting formed business subjects.

5. Getting information about successful politicians, their intentions about entering the business.

6. Finding and identifying the relatives of bank personnel, about whom the bank is interested.

7. Organizing inquiries with friends, relatives and colleagues through managers.

8. Being informed about problem banks and companies.
9. Informing the bank clients about the out-of-duty function activities (consulting, training, tradecooperation and others).

10. Collecting data-base about the potential clients the bank interested in.

11. Defining the territories close to the bank.

12. Sending letters about cooperation with identified potential clients.

13. Holding meetings between the bank and the clients for establishing mutual cooperative relations.

14. Fulfilling the firm decision.

Since deposits increase the banks' crediting competence of the branches of the economy, bases the increasing of the bank services degrees banks use actively the instruments of attracting the spare cash money of physical and juridical persons.

National currency securities issued by banks bonds with the principal value, definitely marked interest rates and deadlines, saving certificates with sums and contracted interest rates are getting more popular. The present credit securities offer to their owners some advantages - they can be: sold to anybody prior to the term-date, gifted, presented as a chart-share of a householding subjects or as a mortgage.

One of the advantages of depositing in the commercial banks by the population in our Republic, different from other developed countries is that the profits from deposits are not taxed and their sources are not declared.

\section{Conclusion}

Similarly, the most liquid, profitable spare cash money savings, physical people's bank accounts as well as their financial operations are considered as a bank secret. The confidence of such information by the commercial banks is guaranteed by law "Bank secrets" and 'State protection guarantee of citizens' bank savings".

In accordance to the law the deposit accounts of physical persons regardless of their volume are guaranteed by the state as well as their complete return by the citizen's first demand.

The growth of people's incomes in our country requires the optimization of bank deposit policy in conformity with market situation. On grounds of expedience the commercial banks are increasing the volume of credit bond securities using their resource base, as well as the following: a) extending the cashless payment system; b) increasing the quantity of cashless payment terminals; c) working out long-term deposit programs using modern update information communication technologies which provides introducing bank plastic cards into wide circulation. 


\begin{tabular}{l|lrl|l|ll} 
& ISRA (India) & $=\mathbf{1 . 3 4 4}$ & SIS (USA) & $=\mathbf{0 . 9 1 2}$ & ICV (Poland) & $=\mathbf{6 . 6 3 0}$ \\
Impact Factor: & ISI (Dubai, UAE) $=\mathbf{0 . 8 2 9}$ & PUHIL (Russia) $=\mathbf{0 . 2 3 4}$ & PIF (India) & $=\mathbf{1 . 9 4 0}$ \\
& GIF (Australia) & $\mathbf{0 . 5 6 4}$ & ESJI (KZ) & $=\mathbf{1 . 0 4 2}$ & IBI (India) & $\mathbf{= 4 . 2 6 0}$ \\
& JIF & $\mathbf{1 . 5 0 0}$ & SJIF (Morocco) & $=\mathbf{2 . 0 3 1}$ & & \\
\hline
\end{tabular}

\section{References:}

1. (2014) Konstitusiya Respubliki Uzbekistan. Sobraniye zakonodatelstva Respubliki Uzbekistan, 2007 g., № 15, st. 152; 2008 g., № 52, st. 510; 2011 g., № 16, st 159; 2014 g., № 16 , st. 176

2. Jukov YF (2001) Dengi, kredit i banki, Uchebnik. M.: YuNITI.

3. Polyak GA (2003) Finansi, denejnoe obraщenie i kredit, Uchebnik. M.: FiS, 2003

4. Kovalevoy AM (2006) Finansi i kredit. Uchebnoe posobie. - M.: Finansi i statistika, 2006. -512 p.

5. Lavrushin OI, et al. (2010) Dengi, kredit, banki. Uchebnik. - M.: KNORUS, 2010. -560 p.

6. Merkulova IV, Lukyanova AY (2010) Dengi, kredit, banki. Uchebnoe posobie. - M.: KNORUS, 2010. - 352 p.
7. Sviridov OY (2006) Finansi, denejnoe obraщenie i kredit. Uchebnoe posobie. - M.: FORUM: INFRA-M, 2006. - 416 p.

8. Vasin YV, Lavrentiev LG (2006) Effective loyalty programs. How to attract and retain customers \3rd ed . - M .: Alpina Business Books , 2006. - p.63.

9. Kendra Lee (2006) Creating a client base : a step by step guide to turn contacts into money $\backslash$ ed. from English. - M .: Vershina, 2006. p.14 .

10. Akhunova GN, et al. (2007) Business strategy : Proc. Guide - TSUE, 2007. - p.43. 